\title{
An Improved Composite Fly Ash Gel to Extinguish Underground Coal Fire in Close Distance Coal Seams: A Case Study
}

\author{
Jun Guo $\mathbb{D}^{1},{ }^{1,2,3}$ Guobin Cai $\mathbb{D}^{1,2}$ Yan Jin, ${ }^{1,3}$ Xuezhao Zheng, ${ }^{1,2,3}$ and Yin Liu $\mathbb{D}^{1,3}$ \\ ${ }^{1}$ School of Safety Science and Engineering, Xi'an University of Science and Technology, Xi'an, Shaanxi 710054, China \\ ${ }^{2}$ Key Laboratory for Prevention and Control of Coal Fires in Shaanxi Province, Xi'an 710054, China \\ ${ }^{3}$ Key Laboratory of Western Mine and Hazard Prevention, Ministry of Education of China, Xi'an, Shaanxi, China \\ Correspondence should be addressed to Jun Guo; guojun@xust.edu.cn, Guobin Cai; 19220214086@stu.xust.edu.cn, and Yin Liu; \\ 18120089021@stu.xust.edu.cn
}

Received 6 April 2020; Accepted 7 May 2020; Published 29 June 2020

Academic Editor: Fernando Lusquiños

Copyright (c) 2020 Jun Guo et al. This is an open access article distributed under the Creative Commons Attribution License, which permits unrestricted use, distribution, and reproduction in any medium, provided the original work is properly cited.

\begin{abstract}
Fire extinguishing with the superior performance of fly ash composite colloid material is a cost-effective colloid fire prevention technology. In this paper, a new powder additive (suspending agent (XK-XJ) and gelling agent) was developed for the existing fire extinguishing technology of fly ash compound colloid. Tests show that the best additions to the fly ash slurry were $0.3 \%$ and $0.1 \sim 0.3 \%$, respectively. The grouting technical scheme of adding a suspending agent on the ground and gelling agent downhole was proposed to solve the problems of solid material settlement and blockage in the long-distance pipeline transportation process. Finally, the optimized fly ash colloid fire prevention and extinguishing technology was successfully applied to the fire control engineering examples of close-range coal seam groups, and the rationality of the developed powder and its proportion was tested, and the feasibility in coal fire control was tested.
\end{abstract}

\section{Introduction}

Occurrence of coal fire disaster is a huge problem faced by all major coal-producing countries in the world; between 1947 and 2006, there were 7757 coal fire accidents in Poland [1], and there were 138 coal fires in the United States from 1990 to 2007 [2], which seriously threatens the safety production of coal and the safety of workers [3, 4]. In India, more than $80 \%$ of coal mine fires are caused by spontaneous combustion [5]. Also, the spontaneous combustion attacks Chinese coal mines seriously [6]. Along with the continuous development of science and technology, coal spontaneous combustion prevention technology has been greatly developed. At present, technologies commonly used in coal mines are leakage plugging, pressure equalization, insert gas, insert foam, threephase foam, atomizing inhibitor, inserting inhibitor, water injection, injection of yellow mud, coal surface spraying, injection gel, and other fire preventing and extinguishing technologies [7-10]. As a new technology, the gel fire preventing and technology has been studied by a large number of scholars since the beginning of 1990s. Three kinds of gel materials have been formed: silicic acid gel, thickened gel, and fly ash solidified material, which has become a kind of important mine fire preventing and fighting technology. The technology integrates the function of plugging, cooling, blocking, and solidifying water so that the easy flowing aqueous solution is gelatinized at a specified time and a position, high-temperature coal body is wrapped, and the endothermic cooling effect of water is fully exerted. The problem of leakage and loss of grouting and water injection is well solved, and the gel will not vaporize rapidly in the open fire at nearly $1000^{\circ} \mathrm{C}$. But it will gradually shrink due to the slow evaporation of water with good fire extinguishing safety and strong applicability $[11,12]$. In China, in the application and popularization process of gel fire preventing and extinguishing technology, several technologies such as in the pit or surface mobile, pipe network type and multifunctional grouting and glue injection fire preventing, and extinguishing system have been developed, which can be flexibly selected according to the actual conditions of mines $[11,13]$. 
The rapid and steady development of gel fire preventing and extinguishing technology has made it successfully widely applied to the prevention and control of coal spontaneous combustion. For example, Jin et al. [14], Zhai et al. [15], and Xiao et al. [16] have respectively analyzed the formation mechanism and characteristics of coal spontaneous combustion in a coal mine and coal outcrop fire area. A comprehensive fire preventing and extinguishing technology scheme mainly composed of polymer colloid and light-paste material and the fire area is successfully treated. In the field of coal spontaneous combustion disaster, fire is the most difficult to prevent and control. In the mining process of close-distance coal seam group, the coal left in the upper layer gob or the nonmined coal body falls into the coal seam gob, or the coal left in the upper layer gob will cause oxidation spontaneous combustion to form coal seam fire under the condition of air leakage and oxygen supply. Of course, gel fire preventing and extinguishing technology is widely used in this kind of fire prevention and control. For example, Guo et al. [17] have successfully treated the fire area with composite gel technology aiming at the phenomenon of spontaneous combustion of the close-distance coal seam group in a mining area. In view of the spontaneous combustion in close-distance coal seam mining in Baijiao Coal Mine of Furong Mining Area in Sichuan Province, Zheng et al. [18] successfully adopted the technology of composite gel and fly ash composite gel to prevent and extinguish fire. Guo et al. [19] and Hu et al. [20, 21] have successfully treated the fire area by using ground drilling and filling gel, threephase foam, and fly ash gel materials combined with inert gas to cover the fire area of close-distance coal seams. Li et al. [22] and Xue et al. [23] have prepared new composite gels for the prevention of spontaneous combustion of coal and successfully treated the fire area. Fan et al. [24] and Zhao et al. [25] have successfully used gel-stabilization foam and grouting technology for drilled pipe to inhibit spontaneous combustion of coal.

Although the gel fire extinguishing materials have been successfully applied in the abovementioned engineering examples and achieved good results, some deficiencies have been exposed in the practical application process, especially when the fly ash/loess composite gel slurry is transported in the long-distance pipeline. The gelling time is not properly controlled and the concentration of gel slurry is too large, and the solid material (fly ash or loess) of the slurry settle due to the difference between the solute and the solution density, which may block the pipeline of the slurry, making it difficult to deliver the fire extinguishing material to the designated position for extinguishing fire. If the long-distance transmission is realized by reducing the concentration of gel slurry, although the problem of pipeline plugging can be solved, it is also difficult to achieve the purpose of extinguishing fire because the effective components of the slurry are too low (gel fire extinguishing agent, fly ash, or loess). In order to solve the abovementioned problems, a technical scheme has been proposed, that is, a suspending agent is added onto the surface of fly ash water solution and a gelling agent is added in the pit to realize long-distance pipeline transportation of fly ash slurry, as shown in Figure 1.
In the scheme, the suspending agent is an additive with suspending and dispersion effect. After the suspending agent is added into the slurry of fly ash or loess, the liquid-solid interface property can be remarkably changed so that the surface tension is lowered and the dispersion system is more stable. This can improve the fluidity of the slurry, reduce the sedimentation speed and the flow resistance of the slurry, effectively prevent sedimentation, and facilitate pipeline transportation. However, due to the different properties of the suspending agent and gelling agent and the respective added amounts, the flow and gelling properties of the slurry are greatly influenced.

On the basis of the existing gel fire extinguishing material, this study conducts a modification test on the fly ash gel material, explores the formula of a new composite gel suspending agent and its optimum addition amount, and deals with the influence of a new suspending agent and gelling agent on sedimentation and gelling properties of fly ash aqueous solution. The fly ash composite gel fire preventing and extinguishing technology is improved, and an industrial test is carried out in a close-distance coal seam group fire control of a mine in Xinjiang to test the fire preventing and extinguishing effect.

\section{Modification Test on Fly Ash Composite Gel}

\subsection{Test Method}

2.1.1. Technical Route. Based on the previous research of the research group, the modification experiment under various conditions is carried out to prepare a new suspending agent, and the optimum addition amount of the suspending agent and gelling agent is determined to improve the performance of fly ash slurry $[11,26]$. Figure 2 shows the technical route of the test.

2.1.2. Test Conditions. For the modification test of the suspending agent, $\mathrm{XK}$ and $\mathrm{XJ}$ are selected as the main components of the suspending agent, and the influence of $\mathrm{XK}$ and $\mathrm{XJ}$ on the sedimentation effect of slurry is studied under the conditions of different mixing ratio and total addition. After adding the suspending agent of different ratio and addition amount to fly ash slurry and after being stirred evenly, the sedimentation height of solid material in slurry at different time is measured. Then, the curve of sedimentation height with time is drawn and the suspending effect under each condition is examined. Each set of data is repeated 5 times in the same conditions, and the average value of the experimental data is taken. Similarly, a modification test is conducted on the gelling agent. The viscosity of the slurry may be used to measure the gelling effect of the gelling agent, and the changing relationship of the viscosity of the slurry may be measured with the components of the added gelling agent.

The test is carried out with fly ash slurry with a watercement mass ratio of $1: 1$. All test conditions are shown in Table 1. 


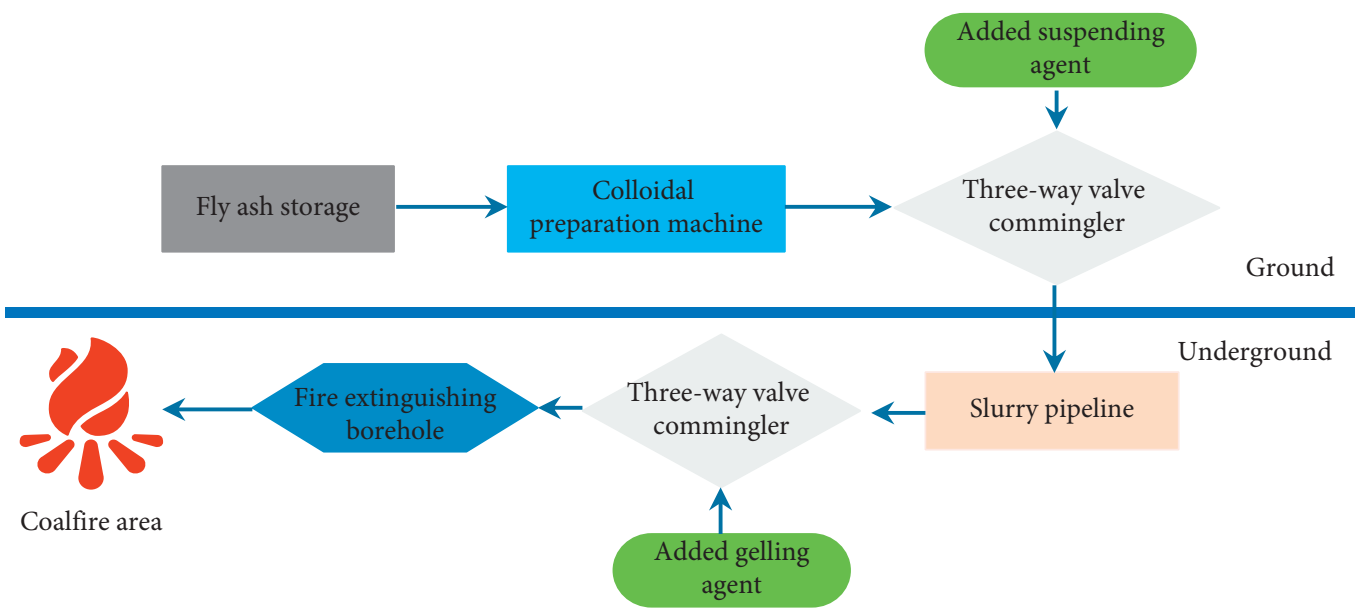

FIgURe 1: Principle of the composite gel fire preventing and extinguishing system.

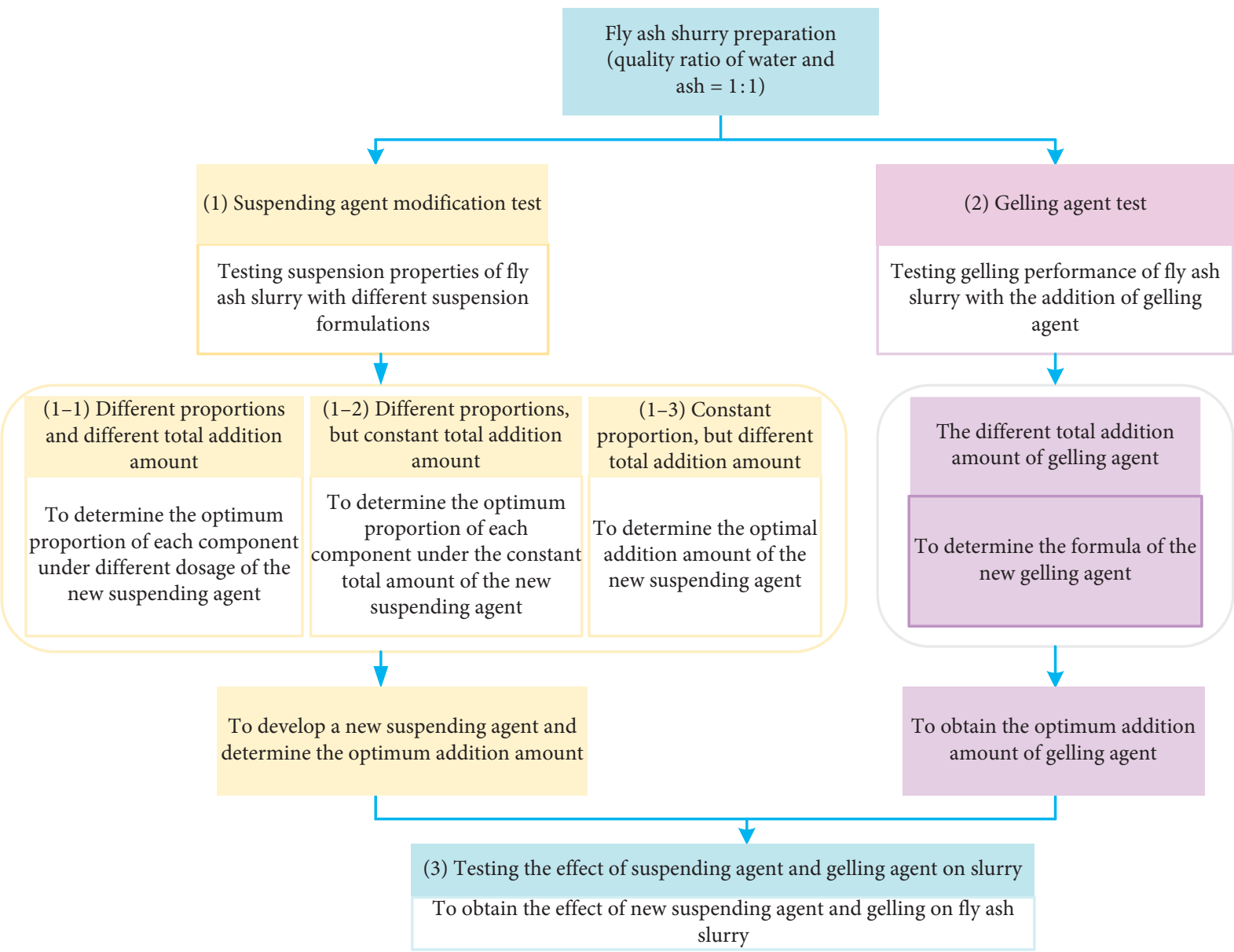

Figure 2: Technical route of the test.

\subsection{Test Result and Discussion}

2.2.1. Modification Test of Suspending Agent. The variation curve of the sedimentation height of the fly ash slurry with time under different conditions and different total additions obtained in the test $(1-1)$ is shown in Figure 3.

As can be seen from Figure 3, when XK:XJ=1:5 (total addition amount is $0.3 \%$ ), the sedimentation speed of the slurry is the slowest, that is, the suspension effect is the best; the sedimentation speed of a blank sample without any additive is the fastest. When $\mathrm{XK}: \mathrm{XJ}=1: 3$ and $1: 13$, the suspension is also good, but it is slightly worse than $1: 5$. When $\mathrm{XK}: \mathrm{XJ}=1: 20$ and $1: 1$, the suspension is poor. The mixture of $\mathrm{XJ}$ and $\mathrm{XK}$ can promote the suspension of fly ash slurry, so $\mathrm{XK}: \mathrm{XJ}=1:(3-13)$ can be controlled. 
TABLe 1: Test conditions.

\begin{tabular}{|c|c|c|c|c|c|c|c|c|c|c|c|c|}
\hline \multirow{3}{*}{$\begin{array}{l}\text { Test } \\
\text { number }\end{array}$} & \multirow{3}{*}{ Class condition } & \multicolumn{10}{|c|}{ Test condition } & \multirow{3}{*}{ Test content } \\
\hline & & & & & & & Group & & & & & \\
\hline & & 1 & 2 & 3 & 4 & 5 & 6 & 7 & 8 & 9 & 10 & \\
\hline \multirow{2}{*}{$(1-1)$} & $\begin{array}{l}\text { Total addition amount } \\
\text { of suspending agent (\%) }\end{array}$ & - & 0.1 & 0.2 & 0.3 & 0.4 & 0.5 & 0.7 & 0.8 & 0.9 & 1.05 & \multirow{6}{*}{$\begin{array}{l}\text { Settlement height of } \\
\text { slurry at different time } \\
\qquad(\mathrm{cm})\end{array}$} \\
\hline & $\begin{array}{c}\text { Mass ratio of XK and XJ } \\
(\mathrm{XK} 0.05 \%)\end{array}$ & - & $1: 1$ & $1: 3$ & $1: 5$ & $1: 7$ & $1: 9$ & $1: 13$ & $1: 15$ & $1: 17$ & $1: 20$ & \\
\hline \multirow{2}{*}{$(1-2)$} & $\begin{array}{l}\text { Total addition amount } \\
\text { of suspending agent (\%) }\end{array}$ & 0.3 & 0.3 & 0.3 & 0.3 & 0.3 & 0.3 & 0.3 & 0.3 & 0.3 & 0.3 & \\
\hline & $\begin{array}{c}\text { Quality ratio of XK and } \\
\text { XJ }\end{array}$ & $1: 1$ & $1: 2$ & $1: 3$ & $1: 4$ & $1: 5$ & $1: 6$ & $1: 7$ & $1: 9$ & $1: 11$ & $1: 13$ & \\
\hline \multirow{2}{*}{$(1-3)$} & $\begin{array}{l}\text { Total addition amount } \\
\text { of suspending agent (\%) }\end{array}$ & 0 & 0.3 & 0.3 & 0.1 & 0.2 & 0.3 & 0.4 & 0.5 & 0.6 & 0.7 & \\
\hline & $\begin{array}{c}\text { Quality ratio of XK and } \\
\text { XJ }\end{array}$ & - & $1: 0$ & $0: 1$ & $1: 5$ & $1: 5$ & $1: 5$ & $1: 5$ & $1: 5$ & $1: 5$ & $1: 5$ & \\
\hline \multirow{2}{*}{ (2) } & Total addition amount & 0 & 0.05 & 0.1 & 0.15 & 0.2 & 0.25 & 0.3 & 0.35 & 0.4 & 0.45 & \multirow{5}{*}{$\begin{array}{l}\text { Viscosity coefficient } \\
\text { (MPa.s) }\end{array}$} \\
\hline & of gelling agent (\%) & 0.5 & 0.55 & 0.6 & 0.65 & 0.7 & 0.75 & 0.8 & 0.85 & 0.9 & 0.95 & \\
\hline \multirow[b]{3}{*}{ (3) } & The addition amount of & 0 & 0.05 & 0.1 & 0.15 & 0.2 & 0.25 & 0.3 & 0.35 & 0.4 & 0.45 & \\
\hline & gelling agent (\%) & 0.5 & 0.55 & 0.6 & 0.65 & 0.7 & 0.75 & 0.8 & 0.85 & 0.9 & 0.95 & \\
\hline & $\begin{array}{l}\text { The addition amount of } \\
\text { new suspending agent } \\
(\%)\end{array}$ & \multicolumn{10}{|c|}{$\begin{array}{l}\text { New suspending agents of } 0,0.25,0.3 \text {, and } 0.35 \% \text { are selected, respectively, } \\
\text { and mixed with the gelling agent added to the abovementioned amount in } \\
\text { turn, and then mixed with fly ash slurry, respectively }\end{array}$} & \\
\hline
\end{tabular}

Note. The ratio in the table is mass ratio; "-" means that the corresponding suspending agent or pour point depressant is not added.

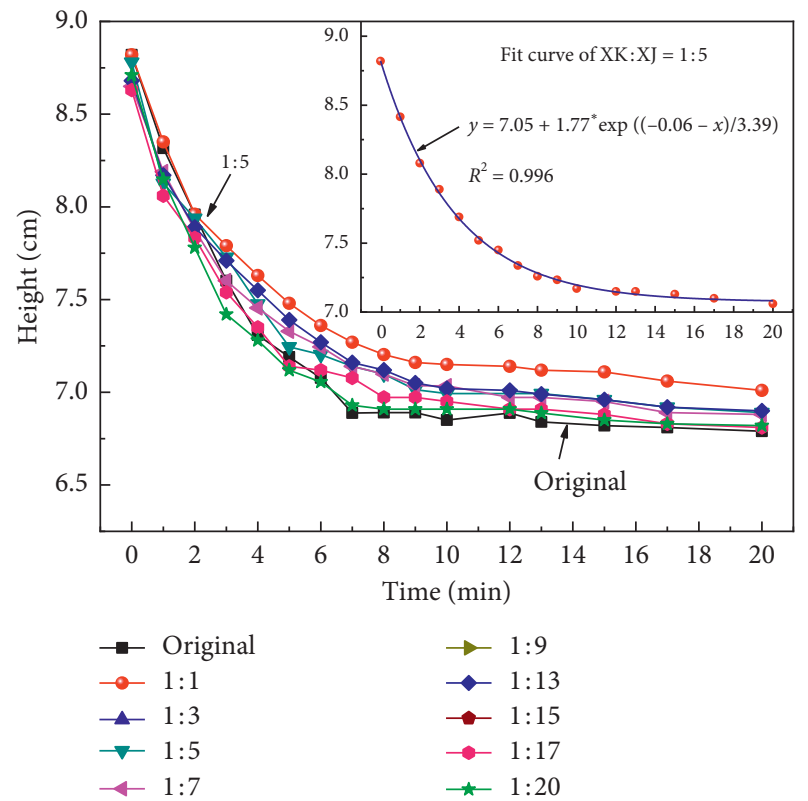

Figure 3: Variation of sedimentation height of fly ash slurry with time in test $(1-1)$.

The variation curve of the sedimentation height of the fly ash slurry with time under the condition of different ratios and constant total additive amount obtained by the test (1-2) is shown in Figure 4.

It can be seen from Figure 4 that, when the total additive amount is the same, the difference between the ratio of XK and $\mathrm{XJ}$ on the influence of sedimentation speed is not obvious, but the overall performance is still that $\mathrm{XK}: \mathrm{XJ}=1: 5$ is the best.

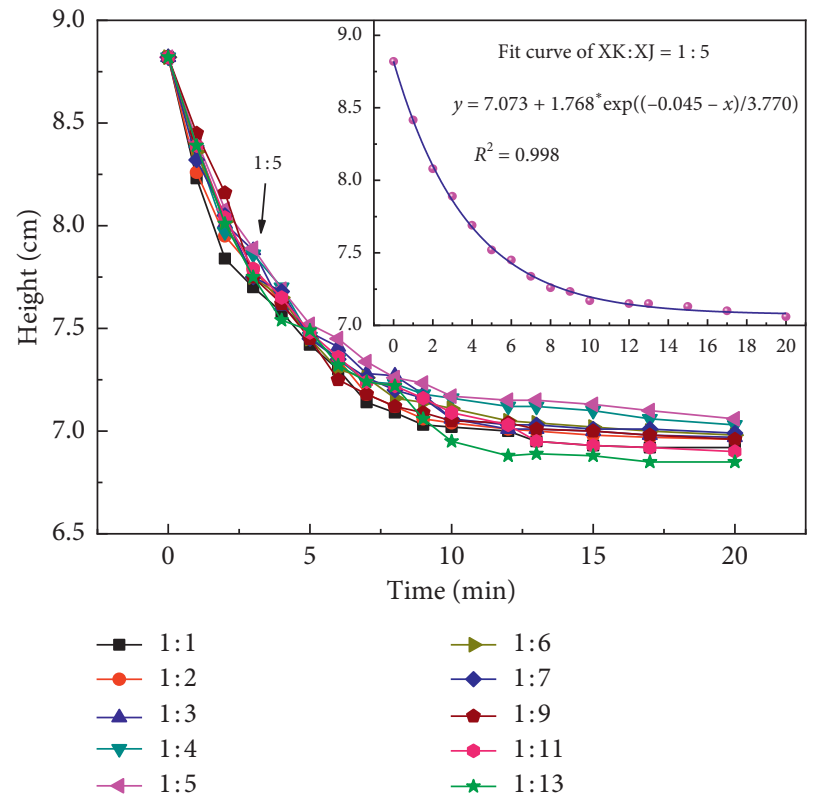

FIGURE 4: Variation of sedimentation height of fly ash slurry with time in test (1-2).

The sedimentation height of fly ash slurry changes with time under the condition of the same ratio and different total additive amounts as shown in Figure 5.

As can be seen from Figure 5, the addition of pure XK or pure XJ contributes to the suspension of fly ash slurry to some extent, but the effect is weaker than the addition of the mixture of both. Under the same ratio, with the increase of the total addition amount, the suspension effect is better and the effect is better when the addition amount is $0.3,0.4,0.5$, 


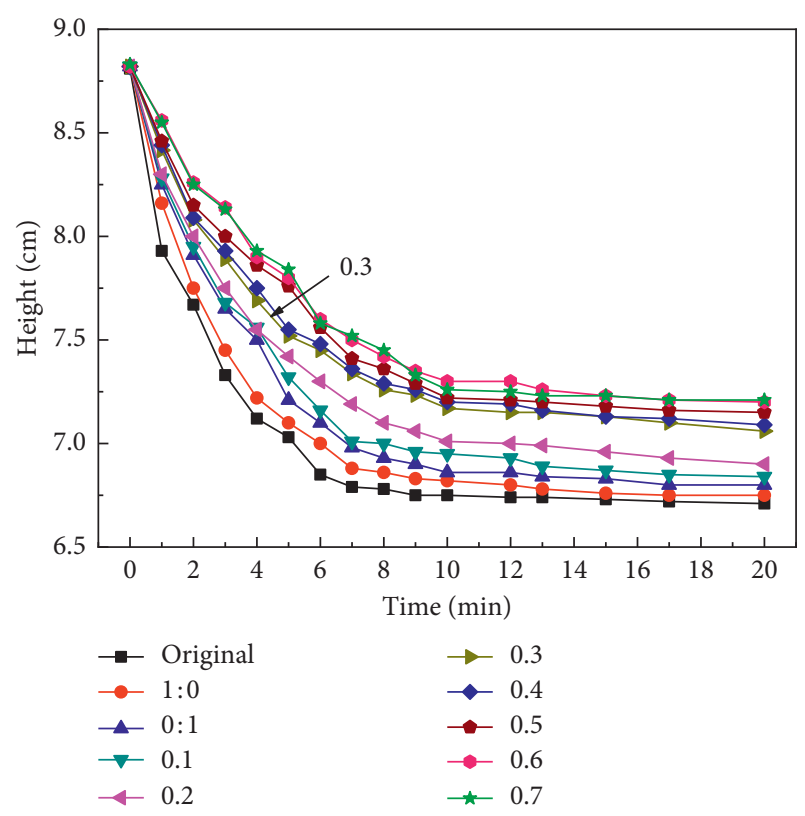

Figure 5: Variation of settlement height of fly ash slurry with time in test (1-3).

0.6 , and $0.7 \%$. The suspending agent with $\mathrm{XK}: \mathrm{XJ}=1: 5$ is optimized when the total amount of suspension is $0.3 \%$ by considering the suspending property and the economic index.

2.2.2. Gelling Agent Test. Figure 6 shows the test results of test (2) and test (3), that is, the influence of different amounts of gelling agent and three kinds of suspending agent $(0.25$, $0.3,0.35 \%)$ on the viscosity of fly ash slurry.

As can be seen from Figure 6, with the addition of a gelling agent, the viscosity of fly ash slurry significantly increases and reaches the first maximum value, when the addition amount reaches $0.1 \%$, and reaches the second maximum value, when the addition amount reaches $0.3 \%$. After that, the viscosity of the slurry slows down with the increase of the amount of gelling agent. The addition of a new suspending agent will not only not destroy the gelling property of fly ash slurry but also promote it to a certain extent. In the practical application process, the addition amount of the gelling agent can be selected according to the on-site requirements of the gelling property. Generally, the addition amount is preferably from 0.1 to $0.3 \%$.

\section{Fire Preventing and Extinguishing Technology of Fly Ash Composite Gel}

The fly ash composite gel material grouting system consists of slurry storage site, slurry transportation and pretreatment system, water supply system, continuous quantitative pulping system, slurry filtering system, additive adding device 1, slurry pressure convey device, slurry conveying pipe network system, additive adding device 2 , and inlet well, as shown in Figure 7. On the ground, fly ash and water are

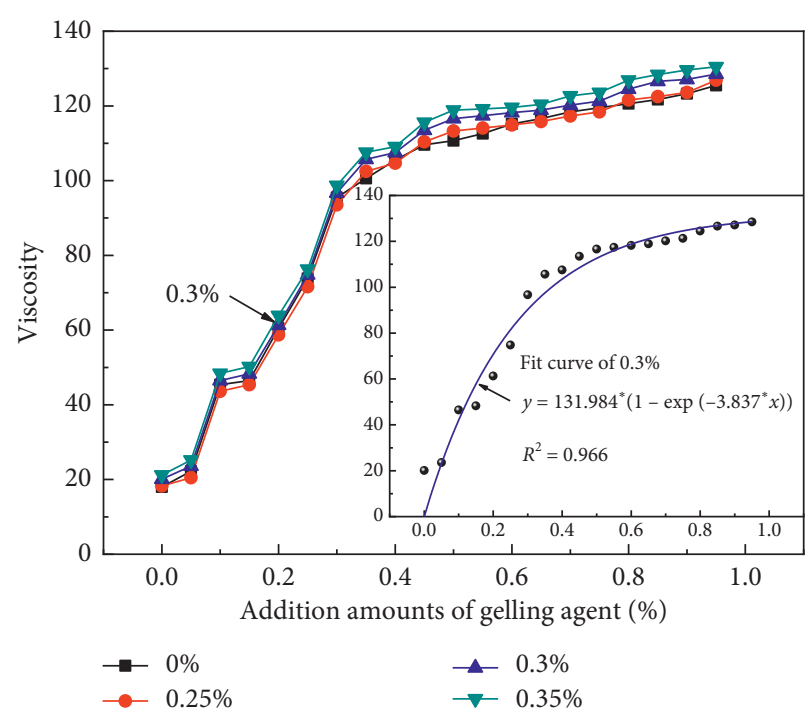

FIGURE 6: Effect of gelling and suspending agents on the viscosity of fly ash slurry.

mixed in proportion by equipment such as gel preparation machine to prepare slurry of desired concentration, and the suspending agent is added to the slurry by the mobile adding device 1 and then transported to the pit through the pipe network. In the pit, the slurry pipeline is connected with the glue injection hole, and the fly ash colloid slurry is injected into the fire zone for fire extinguishing, wherein the addition of the gelling agent is completed by the admixture addition device 2 .

\section{Application Case Study}

4.1. Project Profile. In the paper, the fire extinguishing application of improved fly ash colloid is selected in a mine in Xinjiang, China. In the mine field where a mine is located in Xinjiang (as shown in Figures 8(a) and 8(b)), the coal seams are relatively concentrated, and there are 6 mined coal seams, and the distribution characteristics are shown in Table 2. Coal seams 4, 5, and 6 are main coal seams, belonging to close-distance coal seam mining, lowgas mine, and spontaneous combustion coal seam. During the mining process of $6^{\#}$ coal seam of 2130 footrill, CO is detected in the return airway of 2120 working face, which exceeds $100 \mathrm{ppm}$. It is preliminarily judged that the spontaneous combustion occurs in the floating coal in the 2183 air shaft and the original $5^{\#}$ coal seam in the old mining roadway. A large-scale high-temperature area has been formed in the closed wall, and the development speed is relatively fast. It is possible to develop to 2130 footrill along the arch roadway in a relatively short time for the return airway of 2120 working face of $6^{\#}$ coal seam. In view of the characteristics of unknown fire area scope and degree of spontaneous combustion [27-29], the overall idea of "detecting first, isolating, extinguishing later, and observing the whole process" is adopted to carry out fire area control. The method of radon detection is adopted for fire area detection and the instrument is a CD- 


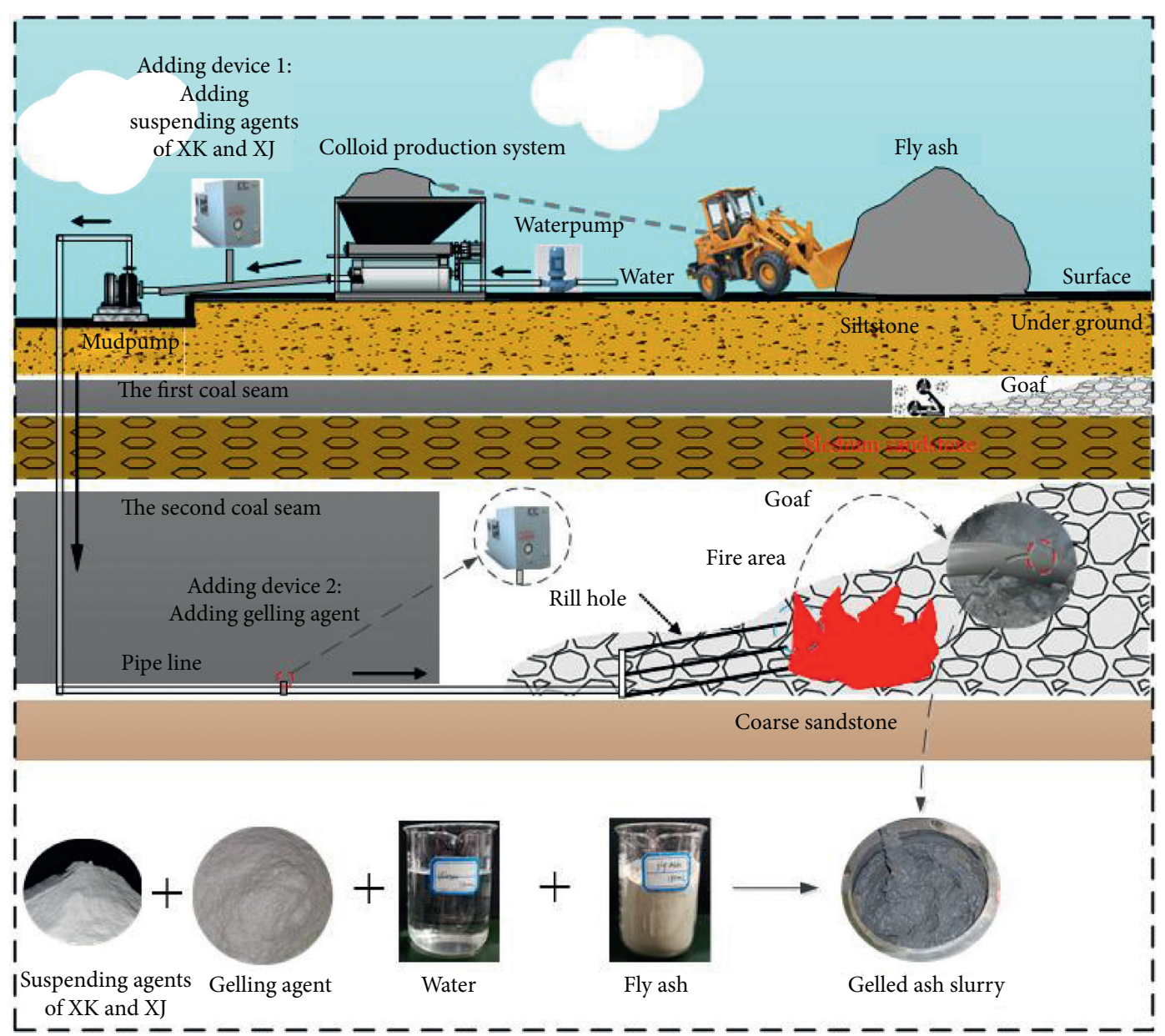

FIgURe 7: Process of the mobile colloid injection system.

$1 \alpha$ cup radon detector [30-32]. The detection range is $800 \mathrm{~m}$ along the east-west direction of the coal seam and $150 \mathrm{~m}$ in the north-south direction, and the total detection area is $12,000 \mathrm{~m}^{2}$. A data processing software package (CDTH software package) is used to perform data processing [27], and a fire range distribution map (Figure 8(c)) is obtained. As can be seen from Figure 8(c), the total area of the fire area is $31,140 \mathrm{~m}^{2}$, and there are 7 high-temperature abnormal zones A, B, C, D, E, F, and G, respectively, with areas of $2,100 \mathrm{~m}^{2}, 1,500 \mathrm{~m}^{2}, 11,600 \mathrm{~m}^{2}$, $340 \mathrm{~m}^{2}, 3,400 \mathrm{~m}^{2}, 3,800 \mathrm{~m}^{2}$, and $8,400 \mathrm{~m}^{2}$, respectively.

4.2. Application of Fly Ash Slurry. In order to better prepare and inject improved fly ash colloids into the fire area, the gel preparation machine and the mobile adding device are respectively "MYZ-30 ground mobile grouting and gel injection fire preventing and extinguishing system" and " $\mathrm{ZHJ}$ 5/1.8 mine-used mobile grouting fire preventing and extinguishing device" developed by the Innovation Team of the Ministry of Education for Prevention and Control of Coal Fire Disaster of Xi'an University of Science and Technology [33], as shown in Figure 9. The area gap is filled with gel, and the total amount of slurry is about $15,350 \mathrm{~m}^{3}$.
Table 3 shows the specific gel process in combination with the goal of filling gel in each area.

4.3. Field Investigation Analyses. When predicting the coal spontaneous combustion process, $\mathrm{CO}$ has always been one of the commonly used index gases, and its existence runs through the entire coal seam spontaneous combustion process $[7,34]$. The fire area is monitored by means of manual detection through ground gel injection drilling hole and special observation hole. CO gas data in the borehole are collected, and the variation curve of CO gas concentration in the fire area with the treatment progress of the fire area is obtained, as shown in Figure 10.

As can be seen from Figure 10, the CO gas data in the observation borehole of the fire area obviously decreases and the fire area is effectively controlled rapidly within one month after the drilling and injection work is carried out. The CO gas concentration in the observation borehole in the fire area decreases from the highest $160 \mathrm{ppm}$ to $40 \mathrm{ppm}$ with the increase of injected gel. The $\mathrm{CO}$ gas concentration in the observation borehole in the fire area reduces to $0 \mathrm{ppm}$ within two months by continuous injection of the subsequent composite gel. After that, the fire area is continuously 


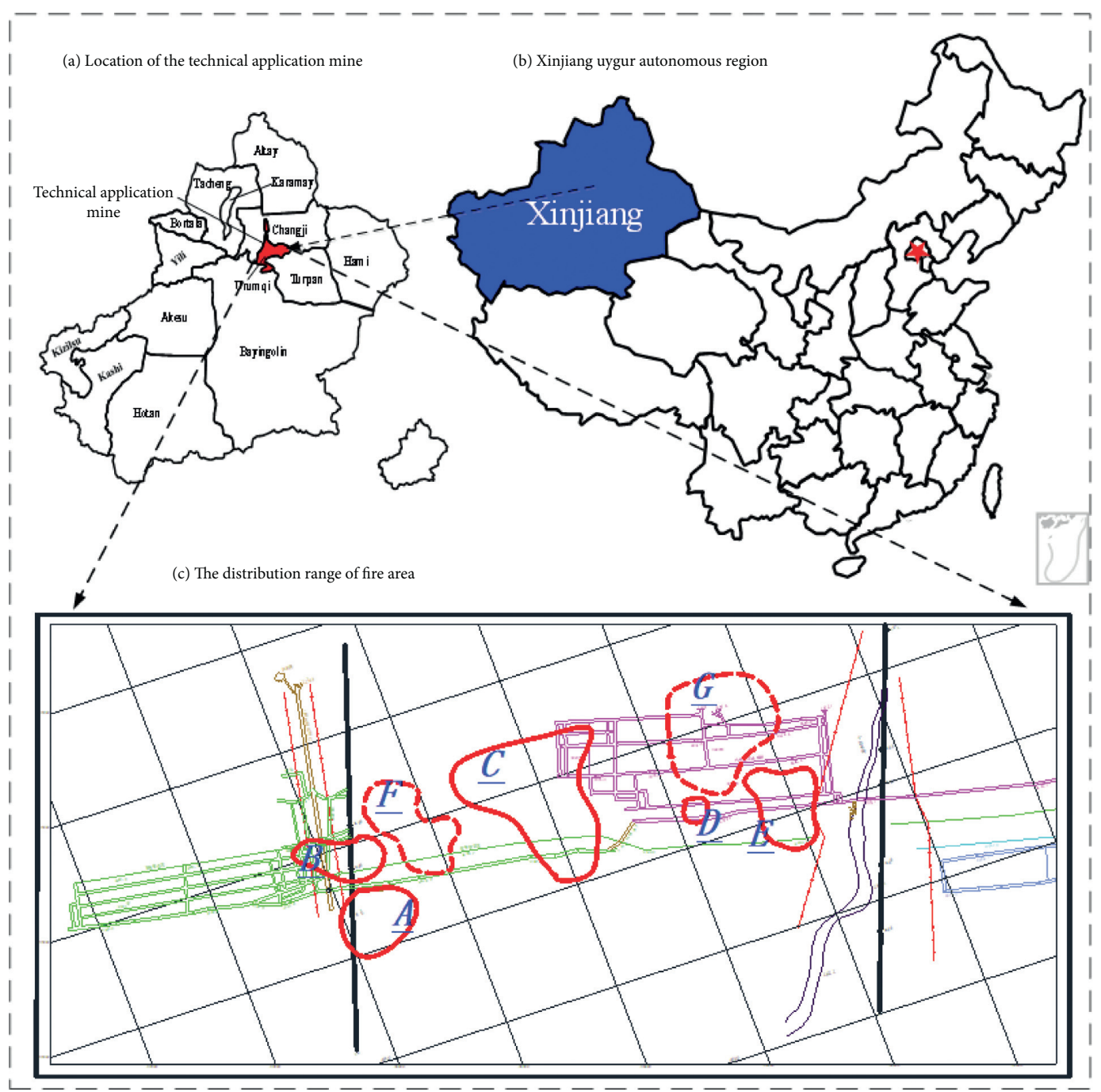

FIGURE 8: Location and fire area of the technical application mine. (a) the enlargement of the blue area in (b). (c) the distribution range of fire area in (a).

TABLE 2: Coal seam features.

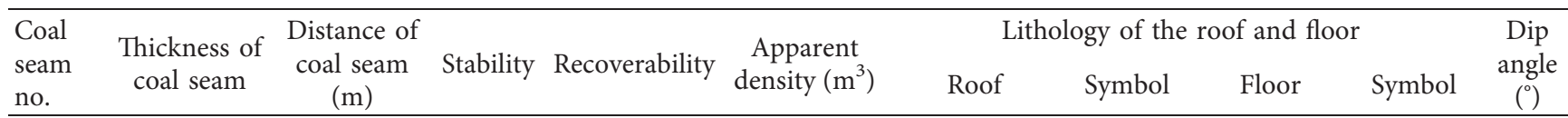

$1 \quad 3.1 \quad 15.93 \quad$ Stable $\quad$ Minable $\quad 1.35 \quad \begin{aligned} & \text { The black } \\ & \text { sandstone }\end{aligned}$

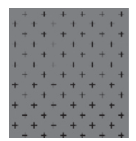


TABle 2: Continued.

\begin{tabular}{|c|c|c|c|c|c|c|c|c|c|c|}
\hline \multirow{2}{*}{$\begin{array}{l}\text { Coal } \\
\text { seam } \\
\text { no. }\end{array}$} & \multirow{2}{*}{$\begin{array}{l}\text { Thickness of } \\
\text { coal seam }\end{array}$} & \multirow{2}{*}{$\begin{array}{l}\text { Distance of } \\
\text { coal seam } \\
(\mathrm{m})\end{array}$} & \multirow{2}{*}{ ability } & \multirow{2}{*}{ Recoverability } & \multirow{2}{*}{$\begin{array}{c}\text { Apparent } \\
\text { density }\left(\mathrm{m}^{3}\right)\end{array}$} & \multicolumn{4}{|c|}{ Lithology of the roof and floor } & Dip \\
\hline & & & & & & Roof & Symbol & Floor & bol & $1^{\circ}$ \\
\hline
\end{tabular}

$3 \quad 39.84 \quad$ Stable Minable $1.35 \quad \begin{gathered}\text { Coarse } \\ \text { sandstone } \\ \text { with quartz }\end{gathered}$

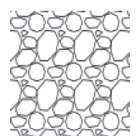

Medium

sandstone

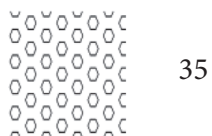

3.26

24.4 Stable Minable

1.35

Gravel

sandstone

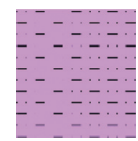

Silstone

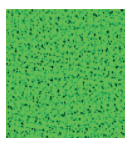

Coarse

sandstone with quartz

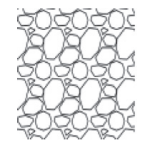

Silstone

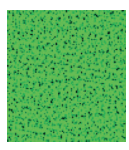

35

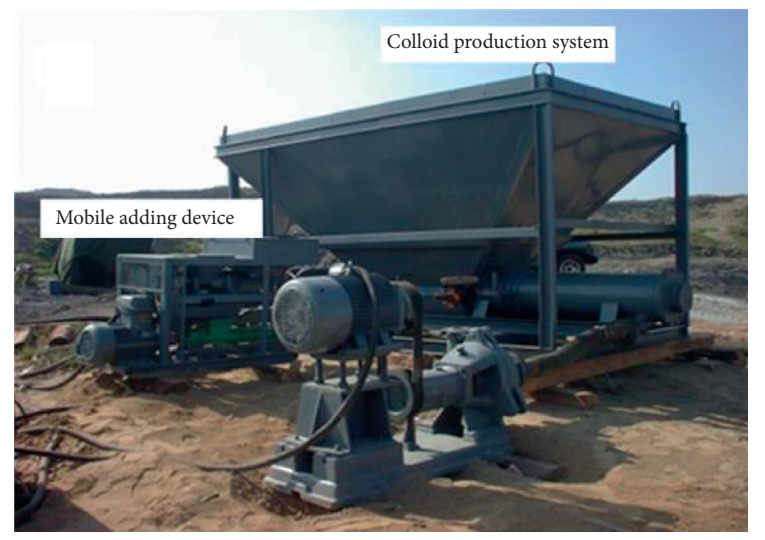

(a)

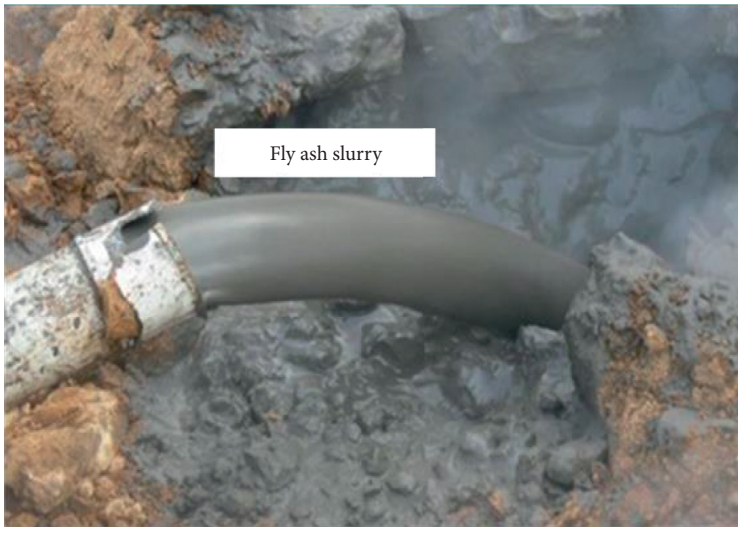

(b)

FIgURE 9: The application of fly ash slurry in the fire area.

TABLE 3: Technological parameters of injection gel.

\begin{tabular}{ccccccc}
\hline No. Filled area & $\begin{array}{c}\text { Amount of } \\
\text { colloid } \\
\text { injected } \\
\left(\mathrm{m}^{3}\right)\end{array}$ & $\begin{array}{c}\text { Quality } \\
\text { ratio of } \\
\text { water and } \\
\text { fly ash }\end{array}$ & $\begin{array}{c}\text { Addition } \\
\text { amount of } \\
\text { gelling agent } \\
(\%)\end{array}$ & $\begin{array}{c}\text { Addition } \\
\text { amount of } \\
\text { suspending } \\
\text { agent }(\%)\end{array}$ & Operating mode & Main purposes \\
\hline $\begin{array}{c}\text { Abandoned } \\
\text { roadway }\end{array}$ & 9000 & $1:(1-1.5)$ & 0.1 & 0.3 & $\begin{array}{c}\text { Discontinuous glue } \\
\text { injection. 3-4 hours of } \\
\text { injection, pause for } \\
\text { about 1 hour }\end{array}$ & $\begin{array}{c}\text { Fully exfoliate the water in } \\
\text { the colloid to increase the } \\
\text { colloid accumulation rate }\end{array}$ \\
\hline
\end{tabular}


TABle 3: Continued.

\begin{tabular}{|c|c|c|c|c|c|c|c|}
\hline No. & Filled area & $\begin{array}{l}\text { Amount of } \\
\text { colloid } \\
\text { injected } \\
\left(\mathrm{m}^{3}\right)\end{array}$ & $\begin{array}{l}\text { Quality } \\
\text { ratio of } \\
\text { water and } \\
\text { fly ash }\end{array}$ & $\begin{array}{c}\text { Addition } \\
\text { amount of } \\
\text { gelling agent } \\
(\%)\end{array}$ & $\begin{array}{l}\text { Addition } \\
\text { amount of } \\
\text { suspending } \\
\text { agent (\%) }\end{array}$ & Operating mode & Main purposes \\
\hline 2 & $\begin{array}{l}\text { Existing } \\
\text { masonry } \\
\text { roadways }\end{array}$ & 1350 & $(1-1.5): 1$ & 0.3 & 0.3 & $\begin{array}{l}\text { Continuous large } \\
\text { amount of glue } \\
\text { injection }\end{array}$ & $\begin{array}{l}\text { Increase the fluidity and } \\
\text { coverage of colloids in the } \\
\text { cracks of high-temperature } \\
\text { coal to improve the fire } \\
\text { extinguishing effect }\end{array}$ \\
\hline 3 & $\begin{array}{l}\text { Roof falling } \\
\text { zone and goaf } \\
\text { area }\end{array}$ & 5000 & $(1-1.5): 1$ & 0.1 & 0.3 & $\begin{array}{l}\text { Discontinuous glue } \\
\text { injection. } 1 \text { hour of } \\
\text { injection, pause for } \\
\text { about half an hour }\end{array}$ & $\begin{array}{l}\text { Release water from the } \\
\text { colloid and fill the fissure } \\
\text { with solid material as much } \\
\text { as possible }\end{array}$ \\
\hline
\end{tabular}
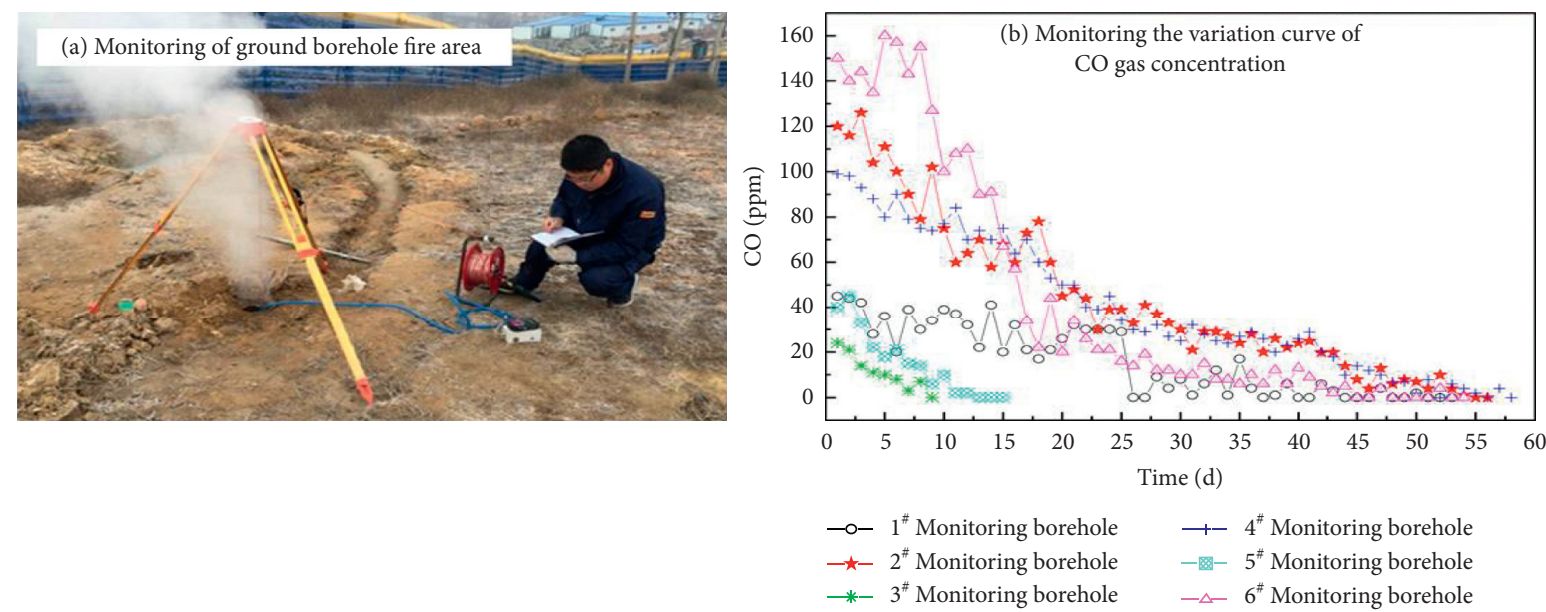

Figure 10: Obtaining CO data through surface drilling monitoring. (a) Monitoring of the ground borehole fire area. (b) Monitoring the variation curve of $\mathrm{CO}$ gas concentration.

observed. The $\mathrm{CO}$ gas concentration is stable at $0 \mathrm{ppm}$ all the time. It can be concluded that the fire area is extinguished.

\section{Conclusions}

(1) The method of adding a suspending agent on the ground and a gelling agent in the pit can effectively improve the long-distance pipeline transportation characteristics of the composite gel slurry, which can ensure good gelling characteristics while solving the sedimentation and plugging of solid material, meeting the actual requirements of on-site firefighting and achieving the purpose of firefighting.

(2) In the modification test of gel, a new suspending agent with $\mathrm{XK}$ and $\mathrm{XJ}$ as main component (mass ratio $\mathrm{XK}: \mathrm{XJ}=1: 3$ ) is developed. It is determined that the optimum addition amounts of the two in the fly ash slurry are $0.3 \%$ and $0.1-0.3 \%$, respectively.

(3) The results show that when the coal spontaneous combustion area is filled with improved fly ash colloid fire extinguishing materials, the carbon monoxide concentration in the fire area is significantly reduced. Extinguishing material has excellent long-distance pipeline transportation capacity and fire extinguishing performance. Therefore, it is reasonable to believe that the environmentally and economically improved fly ash colloid fire extinguishing material will be promoted and applied to control the spontaneous combustion of coal effective means.

\section{Data Availability}

The data used to support the findings of the study are available from the corresponding author upon request.

\section{Conflicts of Interest}

The authors declare that they have no conflicts of interest.

\section{Acknowledgments}

This work was supported financially by the National Key R\&D Program of China (2018YFC0808201); China Postdoctoral Science Foundation (2017M623209); Special Scientific Research Project of Shaanxi Provincial Education 
Department (17JK0495); and Natural Science Basic Research Program of Shaanxi (2018JQ5080, 2018JM5009).

\section{References}

[1] X. Lu, D. Wang, W. Shen, C. Zhu, and G. Qi, "Experimental investigation on liquid absorption of jet pump under operating limits," Vacuum, vol. 114, pp. 33-40, 2015.

[2] R. G. Cunningham, A. G. Hansen, and T. Y. Na, "Jet pump cavitation," Journal of Basic Engineering, vol. 92, no. 3, pp. 483-492, 1970.

[3] A. K. Bharti, S. K. Pal, and P. Priyam, "Subsurface cavity detection over Patherdih colliery, Jharia Coalfield, India using electrical resistivity tomography," Environmental Earth Sciences, vol. 75, pp. 1-17, 2016.

[4] G. B. Stracher, "Coal fires burning around the world: a Global Catastrophe," International Journal of Coal Geology, vol. 59, no. 1-2, pp. 1-6, 2004.

[5] M. Dular, B. Bachert, B. Stoffel, and B. Širok, "Relationship between cavitation structures and cavitation damage," Wear, vol. 257, no. 11, pp. 1176-1184, 2004.

[6] J. Fei and H. Wen, "Experimental research on temperature variation and crack development in coalfield fire," International Journal of Heat and Technology, vol. 35, no. 3, pp. 559-566, 2017.

[7] J. Guo, X. J. Cheng, J. Wu, and S. X. Fan, "CO prediction and control of spontaneous combustion in mining face of thick coal seam inclined to spontaneous combustion," Journal of Safety Science and Technology, vol. 14, pp. 75-81, 2018.

[8] Y. Liu, H. Wen, J. Guo, Y. Jin, G. Wei, and Z. Yang, "Coal spontaneous combustion and N2 suppression in triple goafs: a numerical simulation and experimental study," Fuel, vol. 271, p. $117625,2020$.

[9] H. Wen, Z. Yu, and S. Fan, "Prediction of spontaneous combustion potential of coal in the gob area using CO extreme concentration: a case study," Combustion Science \& Technology, vol. 189, no. 10, pp. 1713-1727, 2017.

[10] H. Wen, Z. Yu, J. Deng, and X. Zhai, "Spontaneous ignition characteristics of coal in a large-scale furnace: an experimental and numerical investigation," Applied Thermal Engineering, vol. 114, pp. 583-592, 2017.

[11] B. Li, G. Liu, W. Gao et al., "Study of combustion behaviour and kinetics modelling of Chinese Gongwusu coal gangue: model-fitting and model-free approaches," Fuel, vol. 268, Article ID 117284, 2020.

[12] H. Wen, S. X. Fan, D. Zhang et al., "Experimental study and application of a novel foamed concrete to yield airtight walls in coal mines," Advances in Materials Science and Engineering, vol. 2018, Article ID 9620935, 2018.

[13] W. Cheng, X. Hu, J. Xie, and Y. Zhao, “An intelligent gel designed to control the spontaneous combustion of coal: fire prevention and extinguishing properties," Fuel, vol. 210, no. 15, pp. 826-835, 2017.

[14] Y. F. Jin, J. Guo, J. L. Qiu, and B. M. Luo, "Study on comprehensive fire prevention technology of fully-mechanized top coal caving face during the period of terminal mining and powered supports withdrawing," Coal Science and Technology, vol. 42, pp. 38-40, 2014.

[15] X. W. Zhai, J. Deng, H. Wen, A. P. Dai, and J. B. Wu, "The research on the thermal destruction of environment and controlling techniques of the No.4 outcrops fire in Haibaoqing," Journal of Coal Science and Engineering (China), vol. 17, no. 3, pp. 345-348, 2011.
[16] Y. Xiao, J. Deng, S. G. Li, X. Liu, and H. P. Wu, "Study and application on fire extinguishing and preventing with lightpaste material for coalmine," Journal of Coal Science and Engineering (China), vol. 17, no. 3, pp. 340-344, 2011.

[17] J. Guo, H. Yan, Y. Liu et al., "Preventing spontaneous combustion of coal from damaging ecological environment based on thermogravimetric analysis," Applied Ecology and Environmental Research, vol. 17, pp. 9051-9064, 2019.

[18] X. Zheng, D. Zhang, and H. Wen, "Design and performance of a novel foaming device for plugging air leakage in underground coal mines," Powder Technology, vol. 344, pp. 842848, 2019.

[19] J. Guo, H. Wen, X. Zheng, Y. Liu, and X. Cheng, "A method for evaluating the spontaneous combustion of coal by monitoring various gases," Process Safety and Environmental Protection, vol. 126, pp. 223-231, 2019.

[20] X. Ren, X. Hu, D. Xue et al., "Novel sodium silicate/polymer composite gels for the prevention of spontaneous combustion of coal," Journal of Hazardous Materials, vol. 371, pp. 643654, 2019.

[21] M. Wu, X. Hu, Q. Zhang, D. Xue, and Y. Zhao, "Growth environment optimization for inducing bacterial mineralization and its application in concrete healing," Construction and Building Materials, vol. 209, pp. 631-643, 2019.

[22] Y. Li, X. Hu, W. Cheng et al., "A novel high-toughness, organic/inorganic double-network fire-retardant gel for coalseam with high ground temperature," Fuel, vol. 263, p. $116779,2020$.

[23] D. Xue, X. Hu, W. Cheng, J. Wei, Y. Zhao, and L. Shen, "Fire prevention and control using gel-stabilization foam to inhibit spontaneous combustion of coal: characteristics and engineering applications," Fuel, vol. 264, p. 116903, 2020.

[24] Y. J. Fan, Y. Y. Zhao, X. M. Hu, M. Y. Wu, and D. Xue, “A novel fire prevention and control plastogel to inhibit spontaneous combustion of coal: its characteristics and engineering applications," Fuel, vol. 263, p. 116693, 2020.

[25] J. Zhao, X. Zhang, N. Jiang, L. Yin, and W. Guo, "Porosity zoning characteristics of fault floor under fluid-solid coupling," Bulletin of Engineering Geology and the Environment, 2020.

[26] J. Deng, Y. Xiao, J. Lu, H. Wen, and Y. Jin, “Application of composite fly ash gel to extinguish outcrop coal fires in China," Natural Hazards, vol. 79, no. 2, pp. 881-898, 2015.

[27] H. Wen, J. Guo, Y. Jin, K. Wang, Y. Zhang, and X. Zheng, "Experimental study on the influence of different oxygen concentrations on coal spontaneous combustion characteristic parameters," International Journal of Oil, Gas and Coal Technology, vol. 16, no. 2, pp. 187-202, 2017.

[28] Y. F. Jin, J. Guo, H. Wen et al., "Experimental study on the high temperature lean oxygen oxidation combustion characteristic parameters of coal spontaneous combustion," Journal of China Coal Society, vol. 40, pp. 596-602, 2015.

[29] H. Wen, J. Guo, Y. F. Jin et al., "Experimental study on effects of moisture on in relation to coal oxidation and spontaneous combustion characteristics of Mengba coal at high temperature environments," Chemical Engineering Transactions, vol. 46, pp. 103-108, 2015.

[30] M. Akram, N. U. Khattak, A. Iqbal, A. A. Qureshi, K. Ullah, and I. E. Qureshi, "Measurement of radon concentration in dwellings of Skardu city, Pakistan," Radiation Measurements, vol. 40, no. 2-6, pp. 695-698, 2005.

[31] S. K. Pal, J. Vaish, and S. Kumar, "Downward continuation and tilt derivative of magnetic data for delineation of concealed coal fire in East Basuria Colliery, Jharia coal field, 
India," Journal of Earth System Science, vol. 126, pp. 53-56, 2017.

[32] S. K. Pal, J. Vaish, S. Kumar, and A. K. Bharti, "Coal fire mapping of East Basuria Colliery, Jharia coalfield using vertical derivative technique of magnetic data," Journal of Earth System Science, vol. 125, no. 1, pp. 165-178, 2016.

[33] Q. Liu, J. Chai, S. Chen et al., "Monitoring and correction of the stress in an anchor bolt based on pulse prepumped brillouin optical time domain analysis," Energy Science \& Engineering, vol. 1, pp. 1-13, 2020.

[34] Y. Liang, J. Zhang, L. Wang, H. Luo, and T. Ren, "Forecasting spontaneous combustion of coal in underground coal mines by index gases: a review," Journal of Loss Prevention in the Process Industries, vol. 57, pp. 208-222, 2019. 